\title{
Thinning intensity and growth response in SW-European Scots pine stands
}

\author{
Miren del Río*, Rafael Calama, Isabel Cañellas, Sonia Roig, Gregorio Montero \\ Centre for Forest Research, INIA, Ctra. A Coruña km 7.5, 28040 Madrid, Spain
}

(Received 7 March 2007; version revised 22 August 2007; accepted 5 October 2007)

\begin{abstract}
The effect of different thinning intensities on growth and yield was studied in Pinus sylvestris L. stands at the south-western limit of its distribution area (Central Spain), using five long-term thinning trials. Data were analysed collectively considering several factors (trial, block, plot and period) as random effects. Total volume and volume increment decreased with thinning intensity, this loss being more significant in the case of moderate and heavy thinning. No difference was found among treatments for total basal area or the increment in basal area. The results revealed an optimum basal area (Assmann's definition) between 85 and $100 \%$ of the basal area in unthinned plots. Volume growth loss associated with heavy thinnings (reduction of $18 \%$ in volume increment) was smaller than that reported in Central and Northern European regions (greater than 25\%). Height increment was not influenced by thinning, whereas dominant and quadratic mean diameter increments increased with the thinning intensity. The response of diameter growth to thinning was greater at younger ages (less than $50 \mathrm{y}$ ) and in medium-sized trees.
\end{abstract}

thinning / Pinus sylvestris / growth / Mediterranean area / long-term trial

Résumé - Intensité d'éclaircie et croissance dans des peuplements de pin sylvestre du sud ouest de l'Europe. L'effet de différentes intensités d'éclaircie sur la croissance et la production de peuplements de Pinus sylvestris L. a été étudié à la limite sud-ouest de sa zone de répartition (centre de l'Espagne), à partir de cinq essais d'éclaircie suivis à long terme. Les données ont été analysées collectivement en prenant en compte différents facteurs (essai, bloc, placeau et période) comme facteurs aléatoires. Le volume total et l'accroissement en volume diminuaient avec l'intensité d'éclaircie, cette perte devenant plus significative dans le cas d'éclaircies modérées et fortes. Aucune différence n'a été trouvée entre traitements pour la surface terrière totale ni pour sa vitesse d'accroissement. Les résultats révèlent un optimum de surface terrière (selon la définition d'Assmann) compris entre $85-100$ \% de la surface terrière des placeaux non éclaircis. Les pertes de croissance en volume associées aux éclaircies fortes (réduction de $18 \%$ ) étaient plus faibles que celles qui sont rapportées pour les régions du Centre et du Nord de l'Europe (supérieures à $25 \%$ ). L'accroissement en hauteur n'a pas été influencé par l'éclaircie alors que l'accroissement quadratique moyen en diamètre augmentait avec l'intensité d'éclaircie. La réponse en termes d'accroissement en diamètre à l'éclaircie a été plus forte pour les jeunes arbres (moins de 50 ans) et les arbres de taille moyenne.

éclaircie / Pinus sylvestris / croissance / région méditerranéenne / essai à long terme

\section{INTRODUCTION}

Besides regeneration felling, thinning is the most commonly applied silvicultural treatment, so the effects of thinning have always been studied as part of forest research science. However, despite the large number of thinning trials analysed, some with very long-term observations, discussion still exists regarding some aspects of the effects of thinning on growth and yield [10, 14, 16, 34, 43, 49].

One of the topics at the forefront of these discussions is Wiedemann's hypothesis [3] or Langsaeter's curve [11], which states that volume increment does not vary across a wide range of densities. Volume increment decreases beneath the lower limit of this range, but there is currently no agreement about what happens when stand density is very high [49]; if the highest volume increment corresponds to the potential maximum basal area [10] or if there is a loss in volume increment at maximum densities [36].

\footnotetext{
* Corresponding author: delrio@inia.es
}

Another subject under discussion is the effect of thinning from below on the diameter growth of individual trees according to their relative size within the stand. Some studies report a lack of response to thinning, or only a slight response, in the diameter growth of larger trees [27,45], whereas others indicate a positive response in all size classes [10,24]. However, the results depend on the studied species and the thinning intensity.

Because of the ecological and economic importance of Scots pine (Pinus sylvestris L.) and its large distribution area in Europe, a large number of thinning studies have been conducted for this species. However, the results of these studies differ regarding the response of the species to thinning, both in terms of volume increment $[20,25]$ and in diameter increment of dominant trees $[8,26]$. It is probable that these conflicting conclusions are in part due to differences in trial and statistical methods [49], which makes it difficult to generalise the conclusions. However, a large ecological variability of the species could also help to explain the discrepancies. Therefore, it is necessary to determine whether there is a common growth 
Table I. Location and description of the thinning trials.

\begin{tabular}{|c|c|c|c|c|c|}
\hline Trial & So-1 & So-2 & Sg-1 & $\mathrm{Sg}-2$ & Bu-1 \\
\hline Altitude (m a.s.1.) & 1200 & 1500 & 1400 & 1750 & 1700 \\
\hline Slope & $15 \%$ & $5 \%$ & $15-20 \%$ & $17 \%$ & $15-20 \%$ \\
\hline Setting year & 1968 & 1968 & 1970 & 1971 & 1972 \\
\hline Age range & $41-76$ & $50-80$ & $45-75$ & $35-65$ & $41-71$ \\
\hline Treatments $^{\mathrm{b}}$ & $\mathrm{C}, \mathrm{T} 1, \mathrm{~T} 2, \mathrm{~T} 3$ & $\mathrm{C}, \mathrm{T} 1, \mathrm{~T} 2$ & $\mathrm{C}, \mathrm{T} 1, \mathrm{~T} 2$ & $\mathrm{C}, \mathrm{T} 1, \mathrm{~T} 2, \mathrm{~T} 3$ & $\mathrm{C}, \mathrm{T} 1, \mathrm{~T} 2$ \\
\hline
\end{tabular}

${ }^{\text {a }}$ Following the site quality model of Rojo and Montero [41].

b Treatments: C, control; T1, light thinning; T2, moderate thinning; T3, heavy thinning.

response to thinning intensity for a given species growing under different ecological conditions. To this end, the analysis of the data with GLM including random components acting at different levels (site, block, plot and inventory) has been proposed in several recent thinning studies [24-26, 45].

In Spain, there are several ongoing thinning experiments in Scots pine stands. In each experimental trial, the results are influenced by site particularities such as initial densities, snow damage, etc. [32, 33, 40]. Not all the trials have been used in these previous studies and a synthetic analysis of all of them has not been undertaken. However, more appropriate methods, and new inventories can contribute to improving the information derived from these trials. It would also be of interest to compare the response to thinning of Scots pine in the Iberian Peninsula, being the south-western limit of its natural distribution, with that detected in other regions. A comparison of yield tables from various European regions revealed a larger production in southern regions [29,37], which could also influence the effects of thinning on growth and yield.

The main objective of this study is to carry out a synthetic analysis of the effects of thinning on the growth and yield of Scots pine stands in the south-western distribution area. The hypothesis is that the response to thinning regarding growth and yield could differ among ecological regions. The cumulative production at different thinning intensities and the density ranges of Langsaeter's curve (density limits at which volume decreases) are analysed, as well as the effect of thinning on both the mean and dominant tree height and diameter growth. The results are compared with those from other experimental trials in central and northern Europe.

\section{MATERIAL AND METHODS}

\subsection{Data}

Data were obtained from 5 thinning trials belonging to a thinning experiment established in 1968 by the Forest Research Centre (CIFOR-INIA) in sites of different fertilities. The thinning trials were located in two of the main mountain regions in which the species is found in Spain, the Iberian and Central Mountain Ranges. All sites belong to the phytoclimatic subtype VIII(VI) [1] and are situated on acidic soils. The trials were installed in pure even-aged stands established through natural regeneration, except for $\mathrm{Sg}-1$, where hole planting was employed using a spacing of $2 \times 2 \mathrm{~m}$. The site locations and the main characteristics of the trials are presented in Table I.

The thinning trials were carried out using a randomised complete block design, with three blocks per site and three or four treatments per block (Tab. I). The trials involved comparing different thinning intensities with a control treatment. All thinnings were undertaken from below and the thinning rotation was 10 years. The age at which the first thinning is performed varies among trials. Due to differences both in thinning intensities and in the number of thinnings applied, treatments were reclassified according to the percentage of average basal area over the whole period in relation to that of the control plots in each trial, using the same interval limits as those proposed by Mäkinen and Isomäki [25,26] for Scots pine thinning experiments in Finland. The treatments tested were the following:

- Control (C) - no thinning. Only dead trees were removed.

- Light thinning (T1) - average basal area $80-90 \%$ of that in the control plots.

- Moderate thinning (T2) - average basal area 65-79\% of that in the control plots.

- Heavy thinning (T3) - average basal area $<65 \%$ of that in the control plots. This treatment was only applied in two experiments (Tab. I).

The plots were rectangular and varied in size from 0.08 to 0.13 ha with 10 -m-wide buffers. The inventory interval was 5 years except for one of 10 years, resulting in 6 or 7 inventories per thinning experiment. In order to gather the data, all trees in each plot were identified with a number and marked at a height of $1.3 \mathrm{~m}$ so that the diameter would always be measured at the same point. In each plot, the diameters of all trees and the height of a sample of 40 trees were measured, 30 of these proportionally to the diameter distribution for mean height estimation and 10 dominant trees for top height estimation.

Height-diameter equations were adjusted for each plot to estimate non-measured tree heights and age was also included as an independent variable [9]. Tree volume was calculated from tree diameter and height using a tree volume function [28]. Stand and tree attributes calculated for each plot and inventory provided the data for the analysis. In Table II, the main stand variables per thinning trial at the beginning of the experiment are shown.

Dead trees were considered as 'removed stand'; therefore, cumulative volume, basal area and their respective increments included 
Table II. Mean and standard deviation (in brackets) of the main stand attributes of the thinning trials at setting year.

\begin{tabular}{|c|c|c|c|c|c|c|c|c|}
\hline Trial & $\begin{array}{c}\text { Age } \\
\text { (years) }\end{array}$ & $\begin{array}{c}\mathrm{N} \\
\text { (trees/ha) }\end{array}$ & $\begin{array}{c}\mathrm{Dg} \\
(\mathrm{cm})\end{array}$ & $\begin{array}{l}\text { Do } \\
(\mathrm{cm})\end{array}$ & $\begin{array}{l}\mathrm{Hm} \\
(\mathrm{m})\end{array}$ & $\begin{array}{l}\text { Ho } \\
\text { (m) }\end{array}$ & $\begin{array}{c}\mathrm{G} \\
\left(\mathrm{m}^{2} / \mathrm{ha}\right)\end{array}$ & $\begin{array}{c}\mathrm{V} \\
\left(\mathrm{m}^{3} / \mathrm{ha}\right)\end{array}$ \\
\hline$\overline{\text { So-1 }}$ & 41 & $\begin{array}{l}2356.6 \\
(402.5)\end{array}$ & $\begin{array}{l}13.9 \\
(1.2)\end{array}$ & $\begin{array}{l}23.8 \\
(2.2)\end{array}$ & $\begin{array}{c}9.3 \\
(0.6)\end{array}$ & $\begin{array}{l}10.9 \\
(0.8)\end{array}$ & $\begin{array}{l}35.1 \\
(1.9)\end{array}$ & $\begin{array}{l}169.3 \\
(18.1)\end{array}$ \\
\hline So-2 & 50 & $\begin{array}{l}2052.7 \\
(388.0)\end{array}$ & $\begin{array}{l}14.2 \\
(1.3)\end{array}$ & $\begin{array}{l}22.7 \\
(1.5)\end{array}$ & $\begin{array}{c}9.7 \\
(0.5)\end{array}$ & $\begin{array}{l}11.4 \\
(0.4)\end{array}$ & $\begin{array}{l}32.0 \\
(3.1)\end{array}$ & $\begin{array}{l}159.1 \\
(19.8)\end{array}$ \\
\hline Sg-1 & 45 & $\begin{array}{l}1414.9 \\
(204.4)\end{array}$ & $\begin{array}{l}20.2 \\
(1.4)\end{array}$ & $\begin{array}{l}28.0 \\
(2.2)\end{array}$ & $\begin{array}{l}13.1 \\
(0.8)\end{array}$ & $\begin{array}{l}14.2 \\
(1.2)\end{array}$ & $\begin{array}{l}45.0 \\
(4.0)\end{array}$ & $\begin{array}{l}286.7 \\
(40.3)\end{array}$ \\
\hline $\mathrm{Sg}-2$ & 35 & $\begin{array}{l}5495.4 \\
(985.6)\end{array}$ & $\begin{array}{c}9.7 \\
(0.7)\end{array}$ & $\begin{array}{l}20.0 \\
(1.2)\end{array}$ & $\begin{array}{c}6.8 \\
(0.5)\end{array}$ & $\begin{array}{c}8.4 \\
(1.0)\end{array}$ & $\begin{array}{l}39.9 \\
(4.3)\end{array}$ & $\begin{array}{l}147.1 \\
(22.5)\end{array}$ \\
\hline $\mathrm{Bu}-1$ & 41 & $\begin{array}{l}3103.4 \\
(871.7)\end{array}$ & $\begin{array}{l}14.5 \\
(2.2)\end{array}$ & $\begin{array}{l}27.9 \\
(3.7)\end{array}$ & $\begin{array}{l}12.8 \\
(1.5)\end{array}$ & $\begin{array}{l}15.9 \\
(1.6)\end{array}$ & $\begin{array}{l}48.8 \\
(3.2)\end{array}$ & $\begin{array}{l}320.8 \\
(45.6)\end{array}$ \\
\hline
\end{tabular}

N: Stand density; Dg: quadratic mean diameter; Do: dominant diameter; Hm: mean height; Ho: dominant height; G: basal area; V: stand volume.

dead trees. All control plots show density-dependent mortality or selfthinning, but not all of them have the maximum density [39]. The mean annual mortality rate in control plots is $1.65 \%$, varying from $0.96 \%$ to $2.59 \%$.

\subsection{Dependent variables}

The effect of different thinning intensities on growth and yield was evaluated by analysing both stand and average tree attributes as dependent variables, either cumulative values or absolute and relative increments. The variables analysed were: V, cumulative volume $\left(\mathrm{m}^{3} / \mathrm{ha}\right)$ (current volume plus volume removed in the thinnings); VI, volume increment $\left(\mathrm{m}^{3} /\right.$ ha/year $)$; $\mathrm{VI}_{\text {rel }}$, relative volume increment (volume increment/stand volume at the beginning of the growth period); $\mathrm{VI}_{\mathrm{T}} / \mathrm{VI}_{\mathrm{C}}$, volume increment in thinning treatments $\left(\mathrm{VI}_{\mathrm{T}}\right)$ in relation to the volume increment in control plots $\left(\mathrm{VI}_{\mathrm{C}}\right)(\%)$; $\mathrm{G}$, cumulative basal area $\left(\mathrm{m}^{2} / \mathrm{ha}\right.$ ) (current basal area plus basal area removed in the thinnings); GI, basal area increment $\left(\mathrm{m}^{2} / \mathrm{ha} / \mathrm{y}\right) ; \mathrm{GI}_{\mathrm{rel}}$, relative basal area increment (basal area increment/stand basal area at the beginning of the growth period); Ho, dominant height (m) (mean height of the 100 thickest trees per ha); HoI, dominant height increment $(\mathrm{m} / \mathrm{y})$; $\mathrm{Hm}$, mean height (m); HmI, mean height increment (m/y); Do, dominant diameter $(\mathrm{cm})$ (mean diameter of the 100 thickest trees per ha); DoI, dominant diameter increment $(\mathrm{cm} / \mathrm{y}) ; \mathrm{Dg}$, quadratic mean diameter $(\mathrm{cm})$; and DgI, quadratic mean diameter increment $(\mathrm{cm} / \mathrm{y})$.

\subsection{Langsaeter's curve}

The Langsaeter curve was studied by analysing the relationship between the volume increment in thinned plots in relation to the mean volume increment in control plots $\left(\mathrm{VI}_{\mathrm{T}} / \mathrm{VI}_{\mathrm{C}} \%\right)$ and the residual basal area (percentage of basal area in thinned plots in relation to the mean basal area of control plots) $\left(\mathrm{G}_{\mathrm{T}} / \mathrm{G}_{\mathrm{C}} \%\right)$. According to Assmann [3], this relationship allows the following variables to be defined: Maximum basal area (basal area of control plots, $\mathrm{G}_{\mathrm{T}} / \mathrm{G}_{\mathrm{C}}=100 \%$ ); Optimum basal area (basal area in which the volume increment is maximum); and Critical basal area (basal area in which $5 \%$ of the volume growth is lost).

\subsection{Statistical analysis}

The pattern of correlation between observations can be considered by formulating a mutilevel mixed model including random effects $[42,46,47]$, which define systematic departures from the average value specific to observations coming from the same trial, block (common site effects on different spatial scales) or inventory (temporal dependence). Trial $\times$ treatment, block $($ trial $) \times$ treatment and trial $\times$ inventory $\times$ treatment random interactions were also evaluated. Other complex interactions at three levels or more were not taken into consideration. The proposed expression for the complete mixed model is:

$$
\begin{aligned}
& \left.y_{\mathrm{ijsb}}=f\left(\text { treat }_{\mathrm{i}}, \text { age }_{\mathrm{j}}\right)+\operatorname{trial}_{\mathrm{s}}+\text { block }_{(\text {trial }}\right)_{\mathrm{b}}+\text { treat } \times \text { block }(\text { trial })_{\mathrm{sbi}} \\
& + \text { trial } \times \text { inventory }_{\mathrm{sj}}+\text { trial } \times \text { treat }_{\mathrm{si}}+\text { trial } \times \text { treat } \times \text { inventory }_{\mathrm{sij}}+\varepsilon_{\mathrm{ijsb}}
\end{aligned}
$$

where $y_{\mathrm{ijsb}}$ indicates the observation for the variable $y$ taken in a plot with treatment $i$, located in block $b$ within trial $s$, measured on inventory $j ; f\left(\right.$ treat $_{\mathrm{i}}$, age $_{\mathrm{j}}$ ) represents the fixed part of the model, depending on both treatment effect and time-dependent covariate stand age; trial $_{\mathrm{s}}$, block $(\text { trial })_{b}$, treat $\times$ block $(\text { trial })_{\mathrm{sbi}},(\text { trial } \times \text { inventory })_{\mathrm{sj}}$, (trial $\times$ treatment $)_{\mathrm{si}}$ and (trial $\times$ treatment $\times$ inventory $)_{\mathrm{sij}}$ are random effects, following a normal distribution with mean zero and variance $\sigma_{\mathrm{s}}^{2}, \sigma_{\mathrm{b}}^{2}$, $\sigma_{\text {sbi }}^{2}, \sigma_{\mathrm{sj}}^{2}, \sigma_{\mathrm{si}}^{2}, \sigma_{\text {sij }}^{2}$, respectively; $\varepsilon_{\mathrm{ijsb}}$ are independent and identically distributed residual terms of error, with mean zero and residual variance $\sigma_{\mathrm{e}}^{2}$.

Model (1) represents the complete model. To avoid overparameterisation an iterative sequential procedure was proposed to define the appropriate model structure for each response variable. The initial model evaluated included intercept and treatment as fixed effects along with a completely random structure, including all the random components mentioned in (1). This basic model was compared with models which had the same fixed effects but a simpler random structure (after discarding some of the random components). Contrasts were performed by applying restricted log-likelihood tests after restricted maximum likelihood (REML) estimation. Once a preliminary random structure had been selected, the inclusion of additional fixed effects was evaluated sequentially; testing the inclusion of age, treatment $\times$ age and the quadratic forms age ${ }^{2}$ and treatment $\times$ age $^{2}$ in terms of log-likelihood ratio tests, applied after maximum likelihood (ML) estimation. Quadratic terms in the model were only adjusted after considering linear terms. Each time a fixed effect was selected for inclusion in the model, the random structure was re-evaluated and 
Table III. Estimates of the parameters of fixed effects and covariance parameters of random effects for volume and basal area variables (only shown for significant effects).

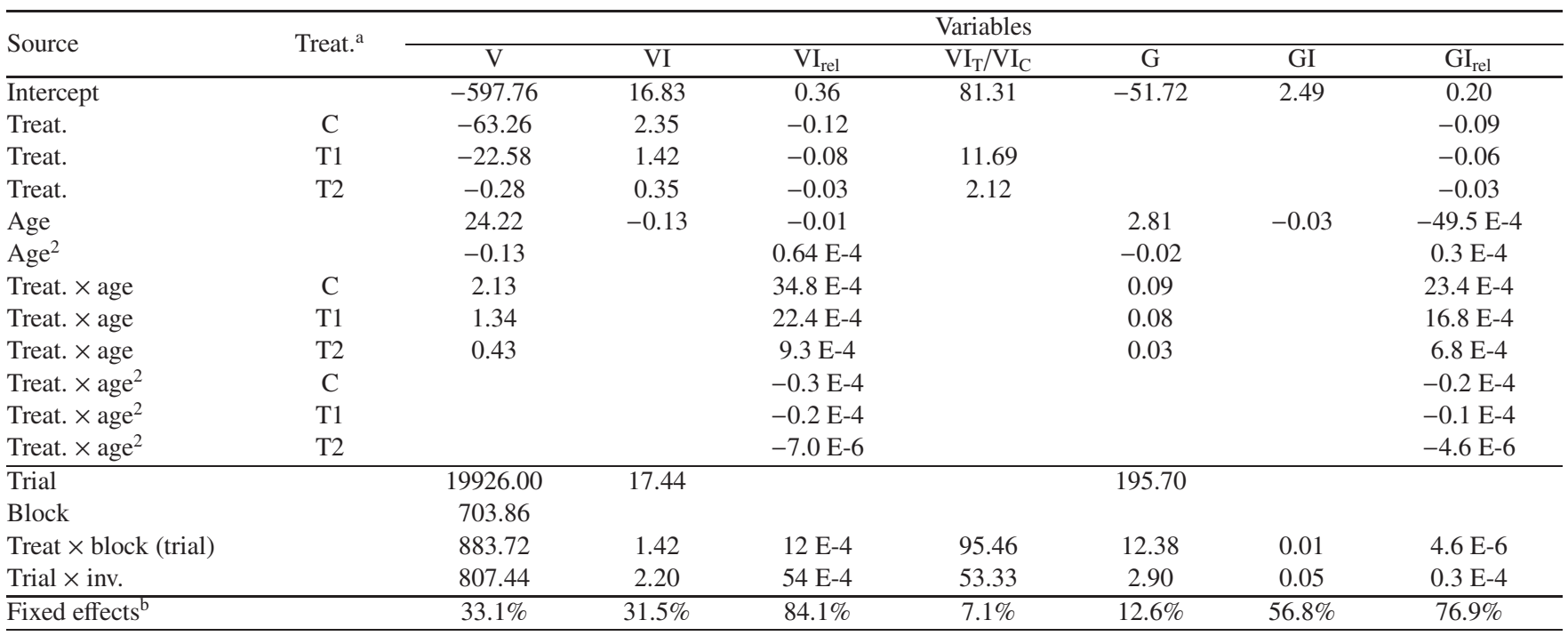

${ }^{a}$ Parameter estimates for treatment T3 are always 0. C: Control; T1: light thinning; T2: moderate thinning; T3: heavy thinning.

${ }^{b}$ Percentage of variability explained by fixed effects. V: Cumulative volume $\left(\mathrm{m}^{3} / \mathrm{ha}\right)$; VI: volume increment $\left(\mathrm{m}^{3} / \mathrm{ha} /\right.$ year $)$; $\mathrm{VI}_{\text {rel }}$ : relative volume increment; $\mathrm{VI}_{\mathrm{T}} / \mathrm{VI}_{\mathrm{C}}$ : volume increment in thinning treatments $\left(\mathrm{VI}_{\mathrm{T}}\right)$ in relation to the volume increment in control plots $\left(\mathrm{VI}_{\mathrm{C}}\right)(\%)$; $\mathrm{G}$ : cumulative basal area $\left(\mathrm{m}^{2} / \mathrm{ha}\right)$; GI: basal area increment $\left(\mathrm{m}^{2} /\right.$ ha/year); $\mathrm{GI}_{\mathrm{rel}}$ : relative basal area increment $(\%)$.

the process was repeated until an appropriate structure for the model was defined.

Once the structure had been defined, the models were fitted following REML techniques. Multiple pairwise comparisons among the adjusted least square means of the treatments at ages 40, 60 and 80 were then performed. Degrees of freedom were adjusted using the Kenward-Rogers procedure [23]. Graphical comparisons were also carried out by plotting the marginal fixed effects response for each treatment.

\section{RESULTS}

\subsection{Cumulative volume and basal area}

The thinning treatment, the quadratic effect of age and the interaction of treatment $\times$ age were statistically significant for cumulative volume, whilst in the case of volume increment, the significant fixed effects were treatment and age (Tab. III). Cumulative volume presented the highest value in non-thinned stands, decreasing with thinning intensity (Fig. 1). Nevertheless, volume loss due to mortality in the control treatment totalled $16.64 \%$ of the cumulative volume at the last inventory. Differences among treatments increased with stand age (Tab. IV). Both in the case of cumulative volume and volume increment, comparisons among treatments revealed only small differences between control plots and those with light thinning treatments as well as between moderate and heavy thinning (Tab. IV). Neither basal area nor its increment presented a significant treatment effect (Tab. III) but the interaction of treatment $\times$ age was significant in the case of basal area, particu- larly at older ages when the differences among treatments were greater (Tab. IV).

Another way to approach the effect of thinning on stand production is to analyse the percentage of volume increment in relation to the mean of the same increment in the control plots $\left(\mathrm{VI}_{\mathrm{T}} / \mathrm{VI}_{\mathrm{C}}\right)$ [3]. The only significant fixed effect for this variable was the thinning treatment, although this explained less than $10 \%$ of the variability (Tab. III). Light thinning values differed from those for moderate and heavy thinning, the percentage volume increment being significantly higher for the former (Tab. IV). The relationship between this percentage of volume increment and the residual basal area (percentage of basal area in thinned plots in relation to the basal area of control plots, $G_{T} / G_{C}$ ), is presented in Table V. It was found that a residual basal area of about $83 \%$ caused a small loss in volume growth $(<8 \%)$ and, as residual basal area decreased (less than $70 \%)$, the drop in volume growth accelerated, reaching a loss of $19 \%$ when basal area in relation to the control was $61 \%$.

\subsection{Relative volume and basal area increments}

Thinning treatment effects and the interactions of treatment $\times$ age and treatment $\times$ age $^{2}$ were found to be significant for relative increments in volume and basal area (Tab. III). These fixed effects explained most of the variability of both increments. Comparisons between treatments revealed statistical differences for all the studied contrasts at younger ages but not at the oldest age (Tab. V). The greater the intensity of the thinning, the higher the relative growth values reached (Fig. 2). 

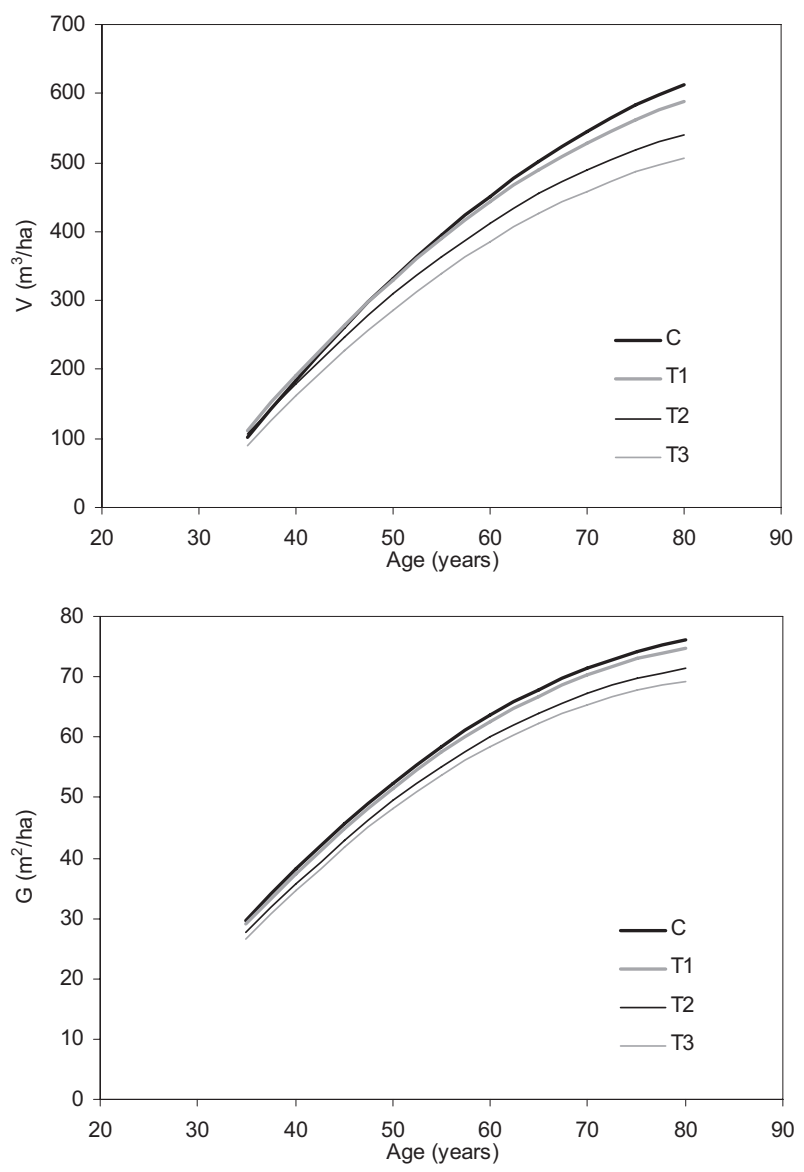

Figure 1. Evolution of cumulative volume (upper) and cumulative basal area (bottom) with age for the different treatments. C: Control; T1: light thinning; T2: moderate thinning; T3: heavy thinning.

\subsection{Mean and dominant height and diameter}

It was found that dominant height was not influenced by thinning, even when heavy thinning was applied (Tab. VI). Neither the mean height nor the increment in this variable showed any significant effects for treatment and the interaction of treatment $\times$ age was found to be significant for mean height only. Differences in mean height between non-thinned and thinned plots were found at older ages (Tab. VII).

The results for dominant diameter revealed a quadratic effect for age and an interaction between age and treatment (Tab. VI). In spite of the significant effect of the thinning treatment on the increment of larger trees, no differences in dominant diameter were detected among the different treatments (Tab. VII). We found significant differences in dominant diameter increment in all the contrasts between treatments except for moderate vs. heavy thinning, while the largest differences occurred between these treatments and the control plots (Tab. VII).

The thinning effect was more obvious for quadratic mean diameter than for dominant diameter (Fig. 3). We found that both the treatment and the interaction of treatment $\times$ age were significant fixed effects for both the quadratic mean diameter
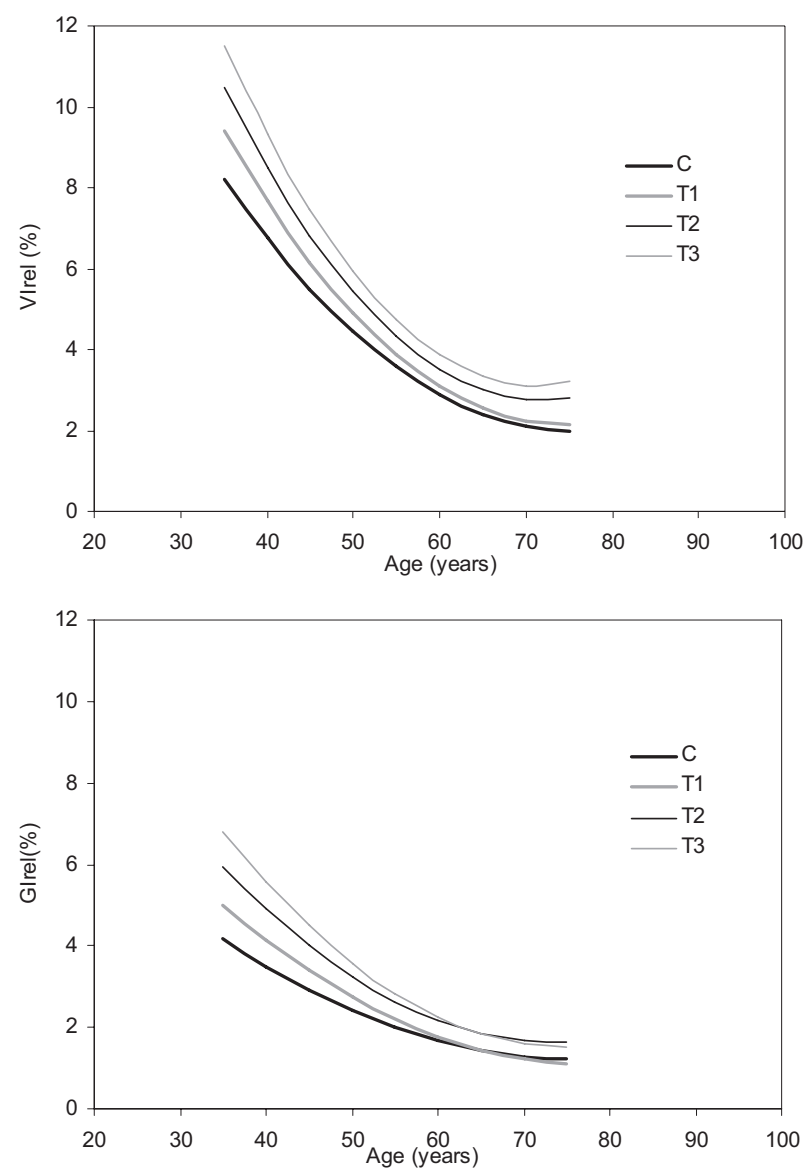

Figure 2. Evolution of relative increments of volume (upper) and basal area (bottom) with age for the different treatments: C: Control; T1: light thinning; T2: moderate thinning; T3: heavy thinning.

and its increment variables, and that treatment $\times \operatorname{age}^{2}$ was also significant for the quadratic mean diameter (Tab. VI). The values of the mean diameter between control plots and thinned plots differed greatly, but differences among the three thinning treatments were not so marked (Tab. VII). The quadratic mean diameter increased with thinning intensity, and these differences became somewhat greater with age. However, regarding the increment in the latter, differences among treatments decreased with age.

\section{DISCUSSION}

\subsection{Cumulative volume and basal area}

There was a significant loss in cumulative volume and volume increment when moderate or heavy thinning were applied, whereas differences were not significant or only slightly significant between light thinning and control treatments. The behaviour of cumulative basal area was similar to that of cumulative volume (same treatment order, Fig. 1) but differences among treatments only appeared at older ages and no 
Table IV. Differences in adjusted least squares means among treatments for volume and basal area variables. Pairwise comparisons at ages 40 , 60 and 80 are presented for those variables for which the treatment $\times$ age effect is significant (variables for which the treatment or treatment $\times$ age effects are not significant are not presented).

\begin{tabular}{|c|c|c|c|c|c|c|c|}
\hline \multicolumn{8}{|c|}{ Contrast between treatments ${ }^{\mathrm{a}}$} \\
\hline Variable & Age & C-T1 & C-T2 & C-T3 & T1-T2 & T1-T3 & T2-T3 \\
\hline \multirow[t]{2}{*}{$\overline{\mathrm{V}}$} & 40 & $-9.237 \mathrm{~ns}$ & $4.733 \mathrm{~ns}$ & $21.779 \mathrm{~ns}$ & $13.970 \mathrm{~ns}$ & $31.016 \mathrm{~ns}$ & $17.046 \mathrm{~ns}$ \\
\hline & 60 & $6.480 \mathrm{~ns}$ & $38.589 *$ & $64.297 * *$ & $32.109 *$ & $57.817 *$ & $25.708 \mathrm{~ns}$ \\
\hline$\overline{\mathrm{VI}}$ & & $0.930 \mathrm{~ns}$ & $1.999 * *$ & $2.350 *$ & $1.069 *$ & $1.420 *$ & $0.351 \mathrm{~ns}$ \\
\hline \multirow[t]{2}{*}{ VIrel } & 40 & $-0.009 * *$ & $-0.016 * *$ & $-0.025 * *$ & $-0.007 *$ & $-0.016 * *$ & $-0.008 *$ \\
\hline & 60 & $-0.002 \mathrm{~ns}$ & $-0.004 *$ & $-0.008 *$ & $-0.002 \mathrm{~ns}$ & $-0.006 *$ & $-0.004 \mathrm{~ns}$ \\
\hline \multirow[t]{3}{*}{$\overline{\mathrm{G}}$} & 40 & $-0.698 \mathrm{~ns}$ & $1.660 \mathrm{~ns}$ & $3.663 \mathrm{~ns}$ & $2.358 \mathrm{~ns}$ & $4.361 *$ & $2.003 \mathrm{~ns}$ \\
\hline & 60 & $-0.194 \mathrm{~ns}$ & $2.917 *$ & $5.336 *$ & $3.111 *$ & $5.530 *$ & $2.419 \mathrm{~ns}$ \\
\hline & 80 & $0.311 \mathrm{~ns}$ & $4.174 *$ & $7.010 *$ & $3.863 *$ & $6.699 *$ & $2.835 \mathrm{~ns}$ \\
\hline \multirow[t]{2}{*}{$\overline{\text { GIrel }}$} & 40 & $-0.007 * *$ & $-0.014 * *$ & $-0.021 * *$ & $-0.007 * *$ & $-0.014 * *$ & $-0.007 *$ \\
\hline & 60 & $-0.003 *$ & $-0.004 * *$ & $-0.007 * *$ & $-0.002 \mathrm{~ns}$ & $-0.005 *$ & $-0.003 *$ \\
\hline
\end{tabular}

${ }^{\text {a }} \mathrm{C}$ : Control; T1: light thinning; T2: moderate thinning; T3: heavy thinning.

ns: Not significant at the 0.05 level; * significant at the 0.05 level; ** significant at the 0.001 level.

V: Cumulative volume $\left(\mathrm{m}^{3} / \mathrm{ha}\right)$; VI: volume increment $\left(\mathrm{m}^{3} / \mathrm{ha} /\right.$ year); $\mathrm{VI}_{\mathrm{rel}}$ : relative volume increment $(\%)$; $\mathrm{VI}_{\mathrm{T}} / \mathrm{VI}_{\mathrm{C}}$ : volume increment in thinning treatments $\left(\mathrm{VI}_{\mathrm{T}}\right)$ in relation to the volume increment in control plots $\left(\mathrm{VI}_{\mathrm{C}}\right)(\%)$; $\mathrm{G}$ : cumulative basal area $\left(\mathrm{m}^{2} /\right.$ ha); $\mathrm{GI}_{\text {rel }}$ : relative basal area increment $(\%)$.

significant loss in basal area increment was observed. Vuokila [48] found a similar behaviour for cumulative basal area in a Finnish thinning trial, but findings for basal area growth are more conflicting, with some reports even finding the highest basal area growth for light thinning $[12,20]$. The effect of the interaction of treatment $\times$ age in cumulative volume and basal area is more related to the cumulative effect of differences among treatments in the respective increments (VI and GI) over time than to a different response to thinning with age, since this effect is not significant for volume and basal area increments.

Cumulative volume and volume increment showed a decreasing trend as thinning intensity increased. Therefore, Langsaester's curve, which shows the pattern of the production-density relationship, would be an increasing asymptotic function, with the highest level of production for basal area ranging from $85-100 \%$ of the potential maximum basal area or density (Fig. 4). Many control plots presented the maximum density according to the self-thinning trajectory proposed by Río et al. [39], but no reduction in growth was detected in any of them.

According to Assmann's approach in his study of the effect of thinning on growth [3], this pattern would mean that the maximum and optimum basal area would have the same value. Other long-term thinning experiments in Scots pine stands found a similar pattern at high densities [12, 19, 25]. Some studies reported a higher volume growth with light thinning (optimum basal area of $90 \%$ ) at younger stages of development $[7,20]$ and in Scots pine forests growing in areas with limited resources (low fertility sites or arctic timberline), as stated by Mielikäinen [31] and Varmola et al. [45]. However, in our study, the lack of significance of trial and age effects with respect to the variable $\mathrm{VI}_{\mathrm{T}} / \mathrm{VI}_{\mathrm{C}}$ (Tab. III) indicates
Table V. Relationship between current increment in volume in thinned plots in relation to the control plots $\left(\mathrm{VI}_{\mathrm{T}} / \mathrm{VI}_{\mathrm{C}}\right)$ and basal area in thinned plots in relation to the control $\left(\mathrm{G}_{\mathrm{T}} / \mathrm{G}_{\mathrm{C}}\right)$ for the different treatments.

\begin{tabular}{lcccc}
\hline & \multicolumn{4}{c}{ Treatment $^{\mathrm{a}}$} \\
\cline { 2 - 5 } & $\mathrm{C}$ & $\mathrm{T} 1$ & $\mathrm{~T} 2$ & $\mathrm{~T} 3$ \\
\hline $\mathrm{G}_{\mathrm{T}} / \mathrm{G}_{\mathrm{C}}(\%)$ & $100 \%$ & $82.74 \%$ & $69.91 \%$ & $61.00 \%$ \\
$\mathrm{VI}_{\mathrm{T}} / \mathrm{VI}_{\mathrm{C}}(\%)$ & $100 \%$ & $92.21 \%$ & $83.44 \%$ & $81.18 \%$ \\
\hline
\end{tabular}

a C: Control; T1: light thinning; T2: moderate thinning; T3: heavy thinning.

a similar behaviour for different site qualities and ages. The relationship between this variable $\left(\mathrm{VI}_{\mathrm{T}} / \mathrm{VI}_{\mathrm{C}}\right)$ and basal area in relation to the control $\left(\mathrm{G}_{\mathrm{T}} / \mathrm{G}_{\mathrm{C}}\right)$ by age classes (Fig. 4) does not reveal any trends with age. Mäkinen and Isomäki [25] also pointed out that the character of volume increment reactions after thinning was independent of site fertility conditions in Finland.

Regarding the loss of volume growth with thinning, the relationship between volume increment in relation to the control $\left(\mathrm{VI}_{\mathrm{T}} / \mathrm{VI}_{\mathrm{C}}\right)$ and basal area in relation to the control $\left(\mathrm{G}_{\mathrm{T}} / \mathrm{G}_{\mathrm{C}}\right)$ (Tab. V) reveals a critical basal area (in which $5 \%$ of the volume growth is lost) over $83 \%$ of the basal area in unthinned stands. This figure agrees with the value proposed by Assmann [3] for Scots pine, which was based on several thinning experiments in Central Europe. Some authors suggest a critical basal area varying with age [7,21], with values from $65-75 \%$ at young ages (approximately 35 years old) and $85-90 \%$ for older stands (from 40 to 55 years). In our study, however, age does not seem to influence this variable $\left(\mathrm{VI}_{\mathrm{T}} / \mathrm{VI}_{\mathrm{C}}\right)$.

The observed volume loss associated with heavy thinning is small compared with that reported for Scots pine in Northern 
Table VI. Estimates of the parameters of fixed effects and covariance parameters of random effects for height and diameter variables (only shown for significant effects).

\begin{tabular}{|c|c|c|c|c|c|c|c|c|c|}
\hline \multirow{2}{*}{ Source } & \multirow{2}{*}{ Treatement $^{\mathrm{a}}$} & \multicolumn{8}{|c|}{ Variables } \\
\hline & & Ho & $\mathrm{HoI}$ & $\mathrm{Hm}$ & $\mathrm{HmI}$ & Do & DoI & $\mathrm{Dg}$ & DgI \\
\hline Intercept & & -5.54 & 0.50 & -7.24 & 0.40 & 3.46 & 0.66 & -16.60 & 0.57 \\
\hline Treatement & $\mathrm{C}$ & & & & & & -0.06 & 14.13 & -0.25 \\
\hline Treatement & $\mathrm{T} 1$ & & & & & & -0.03 & 6.56 & -0.15 \\
\hline Treatement & $\mathrm{T} 2$ & & & & & & -0.01 & 3.16 & -0.08 \\
\hline Age & & 0.54 & -0.005 & 0.53 & $-3.8 \mathrm{E}-3$ & 0.63 & $-5.7 \mathrm{E}-3$ & 0.96 & $-4.7 \mathrm{E}-3$ \\
\hline $\mathrm{Age}^{2}$ & & -0.003 & & $-2.6 \mathrm{E}-3$ & & $-2.9 \mathrm{E}-3$ & & $-4.7 \mathrm{E}-3$ & \\
\hline Treat. $\times$ age & & & & $-11.1 \mathrm{E}-3$ & & -0.02 & & -0.48 & $2.1 \mathrm{E}-3$ \\
\hline Treat. $\times$ age & $\mathrm{T} 1$ & & & $2.8 \mathrm{E}-3$ & & -0.01 & & -0.23 & $1.2 \mathrm{E}-3$ \\
\hline Treat. $\times$ age & $\mathrm{T} 2$ & & & $1.4 \mathrm{E}-3$ & & $5.9 \mathrm{E}-4$ & & -0.12 & 0.7 E-3 \\
\hline Treat. $\times$ age $^{2}$ & $\mathrm{C}$ & & & & & & & $2.6 \mathrm{E}-3$ & \\
\hline Treat. $\times$ age $^{2}$ & $\mathrm{~T} 1$ & & & & & & & $1.4 \mathrm{E}-3$ & \\
\hline Treat. $\times$ age $^{2}$ & $\mathrm{~T} 2$ & & & & & & & $0.8 \mathrm{E}-3$ & \\
\hline Trial $^{\mathrm{a}}$ & & 10.05 & $13.4 \mathrm{E}-4$ & 8.84 & $12.1 \mathrm{E}-4$ & 12.34 & & 11.17 & \\
\hline Block & & & & 0.45 & & & & & \\
\hline Treat $\times$ block (trial) & & 0.92 & & 0.52 & 3.7 E-4 & 5.59 & & 3.67 & $3.5 \mathrm{E}-4$ \\
\hline Trial $\times$ inv. & & 0.25 & $15.8 \mathrm{E}-4$ & 0.22 & $4.9 \mathrm{E}-4$ & 0.08 & 4.1 E-3 & 0.47 & $2.5 \mathrm{E}-3$ \\
\hline Trial $\times$ inv. $\times$ treat & & & & & & & & 0.08 & \\
\hline Fixed effects ${ }^{b}$ & & $39.2 \%$ & $99.4 \%$ & $47.2 \%$ & $99.5 \%$ & $41.3 \%$ & $34.0 \%$ & $60.0 \%$ & $48.0 \%$ \\
\hline
\end{tabular}

a Parameter estimates for treatment T3 are always 0. C: Control; T1: light thinning; T2: moderate thinning; T3: heavy thinning.

${ }^{\mathrm{b}}$ Percentage of variability explained by fixed effects.

Ho: Dominant height (m); HoI: dominant height increment (m/y); Hm: mean height (m); HmI: mean height increment (m/y); Do: dominant diameter $(\mathrm{cm})$; DoI: dominant diameter increment $(\mathrm{cm} / \mathrm{y})$; Dg: quadratic mean diameter $(\mathrm{cm})$; DgI: quadratic mean diameter increment $(\mathrm{cm} / \mathrm{y})$.

Table VII. Differences in adjusted least squares means among treatments for height and diameter variables. Pairwise comparisons at ages 40 , 60 and 80 are presented for those variables for which the treatment $\times$ age effect is significant (variables for which the treatment or treatment $\times$ age effects are not significant are not presented).

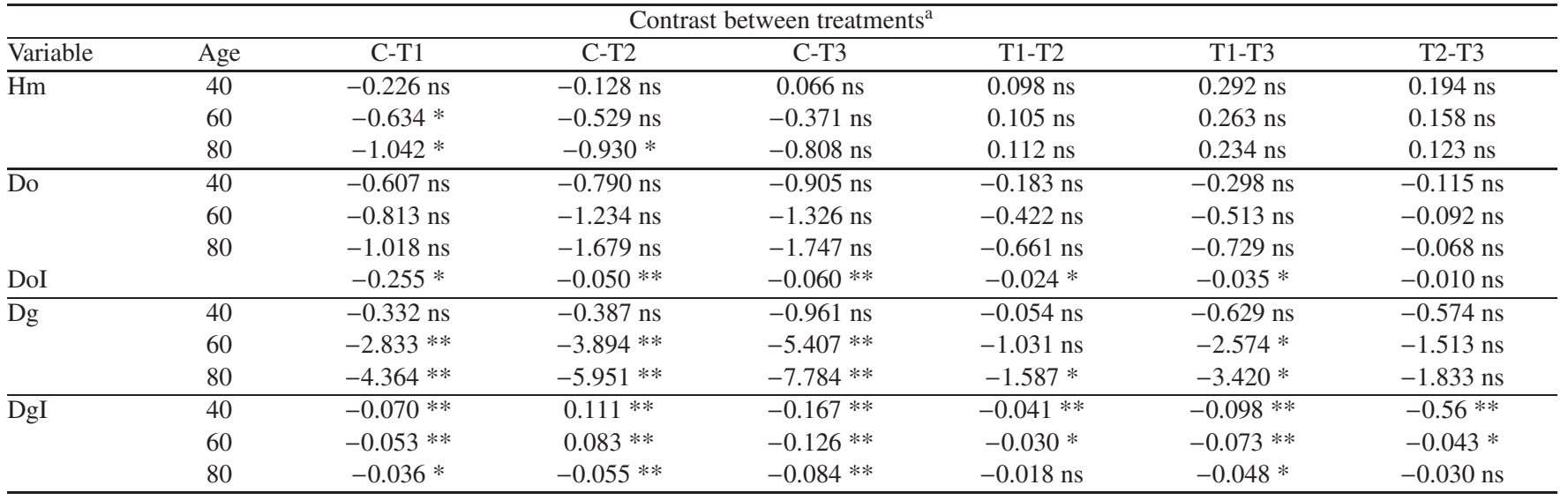

${ }^{a} \mathrm{C}$ : Control; T1: light thinning; T2: moderate thinning; T3: heavy thinning.

ns: Not significant at the 0.05 level; * significant at the 0.05 level; ** significant at the 0.001 level.

Hm: Mean height (m); Do: dominant diameter (cm); DoI: dominant diameter increment (cm/y); Dg: quadratic mean diameter (cm); DgI: quadratic mean diameter increment $(\mathrm{cm} / \mathrm{y})$.

and Central European regions. In these regions, when basal area drops below $65 \%$ of that in the control plots (heavy thinning) volume increment losses reach figures of between 22 and $37 \%[7,21,25,44]$, whereas our results indicated a reduction of $19 \%$ (Tab. V), this percentage being greater than that for non-thinned stands due to natural mortality. In the case of moderate and light thinnings, however, the regional differences detected are much smaller. Erteld's [12] summary concerning
Scots pine thinning experiments in Germany revealed volume increment losses of approximately $10 \%$ for basal area reductions of 20\%. Mäkinen and Isomäki [25] detected volume increment losses of $3-6 \%$ and $12-17 \%$ for light and moderate thinnings. The latter figures coincide with those of our study (Tab. V).

The smaller yield loss with heavy thinnings at lower latitudes could be due to the longer length of the growing season. 

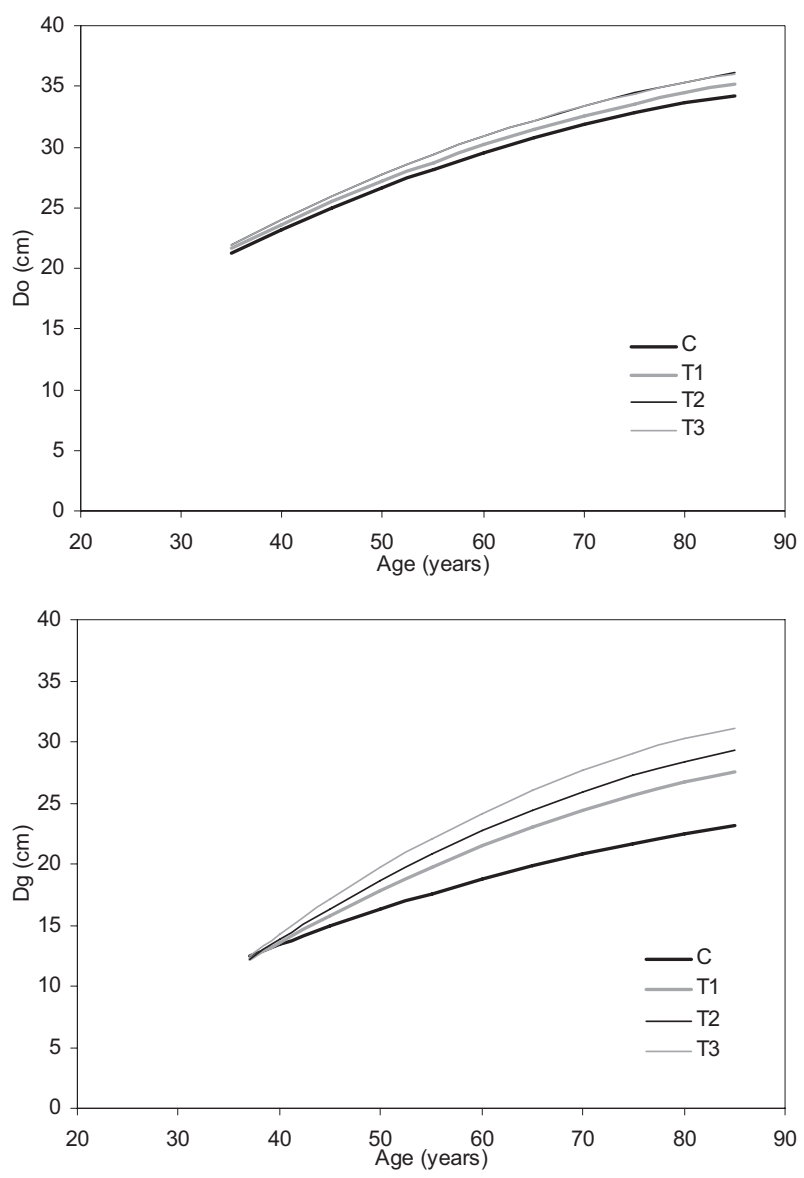

Figure 3. Evolution of dominant diameter (upper) and quadratic mean diameter (bottom) with age for the different treatments: C: control; T1: light thinning; T2: moderate thinning; T3: heavy thinning.

Kellomäki and Kolström [18], using a growth model which included soil and climatic variables, found that the yield loss due to heavy thinning in Scots pine stands in southern Finland was reduced when an increase in the mean temperature was simulated. Several thinning studies have also reported an improvement in tree-water status in heavily thinned stands during the vegetative period if water is a limiting resource $[4,15,22]$. In the southern locations of Scots pine, under Mediterranean conditions, water is the most limiting resource to growth, so the longer growing season could allow the trees remaining after a heavy thinning to compensate more rapidly for the loss of yield associated with the lower density.

\subsection{Relative volume and basal area increments}

Higher relative volume and basal area increments were found for thinning treatments, increasing the growth rate with thinning intensity, although the differences between treatments tended to decrease with age (Fig. 2). This better response to thinning at younger ages reflects the interaction of treatment $x$ age and indicates the suitability of early thinning for this species. On the other hand, differences found in relative basal area increment reveal greater growth for the same basal area when heavy thinning is applied. Some basal area growth models assume that initial basal area and age provide sufficient information to predict future basal area $[2,5,6,30,38]$, but the results for relative basal area increment support the need to include a thinning response factor when modelling basal area growth [17] in Scots pine stands.

\subsection{Mean and dominant height and diameter}

The results confirm that dominant height is not influenced by thinning intensity when thinnings from below are applied, corroborating the suitability of this variable as a site quality indicator. The observed increase in mean height as thinning intensity and age increase (treatment $\times$ age effect) is in fact a technical increment, since the dominated trees were removed in successive thinnings. Other studies have also reported little effect of thinning on height growth for Scots pine $[25,44]$.

One of the objectives of thinning is to produce larger trees, which is clearly achieved by applying heavy thinning from below. According to the results, the heavier the thinning intensity, the higher the quadratic mean diameter. Most of the thinning experiments reported similar results for quadratic mean diameter, but the case is not so clear for dominant diameter. Mäkinen and Isomäki [25] found significant differences in dominant diameter, but in other studies, as in the present study, no differences were reported $[8,45]$.

Both dominant and quadratic mean diameters are influenced by site and initial stand conditions, reflected in the significant trial and treatment $\times$ block (trial) effects (Tab. VI). However, their increments were more influenced by growth period characteristics (trial $\times$ inventory effect). On the other hand, thinning from below produces a technical increment in mean diameters due to the removal of the thinnest trees. Therefore, it is more appropriate to analyse diameter increments since they more faithfully reflect the effect of thinning. The quadratic mean diameter increment increased with thinning intensity and the differences among treatments decreased with age (treatment $\times$ age effect), again revealing that the response to thinning is greater at younger ages [13]. However, the differences among treatments were greater for the quadratic mean diameter increment than for dominant diameter increment (Tab. VII). This result agrees with the findings of Kramer and Röös [21], who found the smallest differences between thinning intensities in the larger diameter classes. Pukkala et al. [35] reported a greater thinning response in medium-sized trees, while Mäkinen and Isomäki [25] found a decreasing thinning effect with increasing tree size. All these results seem to support the idea that in Scots pine stands, thinning from below favours the development of intermediate trees more than dominant trees.

In conclusion, it should be underlined that thinning in Scots pine stands does not lead to an increase in cumulative volume or volume increment. Greater total volume and volume increment are obtained with an optimum basal area of between 85 and $100 \%$, which corresponds to control and light thinning treatments. Basal area increment is not affected by thinning 


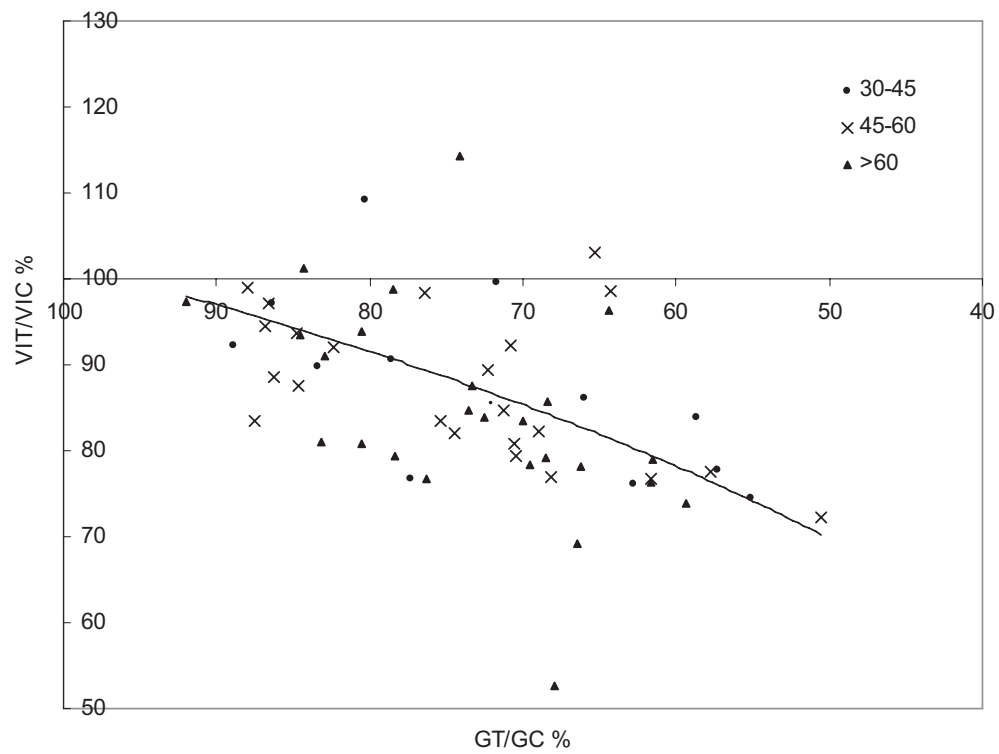

Figure 4. Relationships between volume increment in thinned plots in relation to the control $\left(\mathrm{VI}_{\mathrm{T}} / \mathrm{VI}_{\mathrm{C}}\right)$ and basal area in thinned plots in relation to the control $\left(\mathrm{G}_{\mathrm{T}} / \mathrm{G}_{\mathrm{C}}\right)$ by age classes: $30-45$ years old, $45-60$ years old; $>60$ years old. The solid line is the trends line for all data.

intensity and neither are mean or dominant height increments. Thinning does, however, influence diameter increment, especially in medium-sized trees. In general, our results agree with those from long-term experiments. The main regional differences found between southern and northern European growth patterns after thinning are related to volume loss after heavy thinning, with smaller losses in SW-European stands.

Acknowledgements: The authors wish to thank the CIFOR-INIA for providing data and funds to maintain the thinning plots network (Research Project OT 03-002). Thanks to all the people who have contributed to the installation, maintenance and periodic inventorying of the CIFOR-INIA thinning experiments, particularly to Angel Bachiller and Ricardo Ruiz- Peinado.

\section{REFERENCES}

[1] Allue J.L., Atlas fitoclimático de España, Monografías del INIA $n^{\circ}$ 69, 1990.

[2] Amaro A., Tomé M., Themido I., Stand growth modelling for first rotation Eucalyptus globulus Labill. in Portugal, in: Empirical and process-based models for forest tree and stand growth simulation, Amaro A., Tomé M (Eds.), Ediçoes Salamandra, Oeiras (Portugal), 1997, pp. 99-110.

[3] Assmann E., The principles of forest yield study, Pergamon Press, Oxford, 1970.

[4] Breda N., Granier A., Aussenac G., Effects of thinning on soil and water relations, transpiration and growth in an oak forest (Quercus petraea (Matt.) Liebl.), Tree Physiol. 15 (1995) 295-306.

[5] Bravo-Oviedo A., Río M., Montero G., Site index curves and growth model for Mediterranean maritime pine (Pinus pinaster Ait.) in Spain, For. Ecol. Manage. 201 (2004) 187-197.

[6] Castedo-Dorado F., Diéguez-Aranda U., Barrio-Anta M., ÁlvarezGónzalez J.G., Modelling stand basal area growth for radiata pine plantations in Northwestern Spain using the GADA, Ann. For. Sci. 64 (2007) 609-619.
[7] Chroust L., Thinning experiment in a Scots pine forest stand after 20 years investigation, Comm. Inst. For. Chec. 11 (1979) 61-75.

[8] Chroust L., Thinning experiment in a Scots pine forest stand after 40-year investigations, J. For. Sci. 47 (2001) 356-365.

[9] Curtis R.O., Height-diameter and height-diameter-age equations for second growth Douglas fir, For. Sci. 13 (1967) 365-375.

[10] Curtis R.O., Marshall D.D., Bell J.F., LOGS: A pioneering example of silvicultural research in coast Douglas-fir, J. For. 95 (1997) $19-25$.

[11] Daniel T.W., Helms J.A., Baker F.S., Principles of silviculture, 2nd ed., McGraw-Hill Book Co., New York, 1979.

[12] Erteld W., Untersuchung über Leistung und Entwicklung der Kiefer bei verschiedener Behandlung, Arch. Forstw. 9 (1960) 326-364.

[13] Franz F., Zur Behandlung und Wuchsleistung der Kiefer, Forstw. Cbl. 102 (1983) 18-36.

[14] Gilmore D.W., O’Brien T.C., Hoganson H.M., Thinning red pine plantations and the Langsaeter hypothesis: a Northern Minnesota case study, North. J. Appl. For. 22 (2005) 19-26.

[15] Ginn S.E., Seiler J.R., Cazell B.H., Kreh R.E., Physiological and growth response of eight-year-old loblolly pine stands to thinning, For. Sci. 37 (1991) 1030-1040.

[16] Guller B., The effects of thinning treatments on density, MOE, MOR and maximum crushing strength of Pinus brutia Ten. wood, Ann. For. Sci. 64 (2007) 467-475.

[17] Hasenauer H., Burkhart H.E., Amateis R.L., Basal area development in thinned and unthinned loblolly pine plantations, Can. J. For. Res. 27 (1997) 265-271.

[18] Kellomäki S., Kolström M., Computations on the yield of timber by Scots pine when subjected to varying levels of thinning under a changing climate in southern Finland, For. Ecol. Manage. 59 (1993) 237-255.

[19] Kojola S., Penttilä, Laiho R., Impacts of different thinning regimes on the yield of uneven-structured scots pine stands on drained peatland, Silva Fenn. 38 (2004) 393-403.

[20] Kramer H., Jünemann D., Bestandesentwicklung und Erstdurchforstung bei einem weitständig begründeten Kiefernbestand, Forstarchiv. 55 (1984) 10-17. 
[21] Kramer H., Röös M., Durchforstungsversuch in einem weitständig begründeten Kiefernbestand, Forst. Holz 44 (1989) 139-144.

[22] Laurent M., Antoine N., Jöel G., Effects of different thinning intensities on drought response in Norway spruce (Picea abies (L.) Karst.), For. Ecol. Manage. 183 (2003) 47-60.

[23] Littell R.C., Stroup W.W., Freund R.J., SAS for linear models. SAS Institute, Cary, N.C., 2002.

[24] Mäkinen H., Isomäki A., Thinning intensity and long-term changes in increment and stem form of Norway spruce trees, For. Ecol. Manage. 201 (2004) 295-309.

[25] Mäkinen H., Isomäki A., Thinning intensity and growth of Scots pine stands in Finland, For. Ecol. Manage. 201 (2004) 311-325.

[26] Mäkinen H., Isomäki A., Thinning intensity and long-term changes in increment and stem form of Scots pine trees, For. Ecol. Manage. 203 (2004) 21-34.

[27] Marquis D.A., Ernst R.L., The effects of stand structure alter thinning on the growth of an allegheny harwood stand, For. Sci. 37 (1991) 1182-1200.

[28] Martínez-Millán F.J., Ara P., Gonzalez-Doncel I., Ecuaciones alométricas de tres variables: estimación del volumen, crecimiento y porcentaje de corteza de las principales especies maderables españolas, Invest. Agrar., Sist. Recur. For. 2 (1993) 211-228.

[29] Mason W.L., Alía R., Current and future status of Scots pine (Pinus sylvestris L.) forests in Europe, Invest. Agrar., Sist. Recur. For. Fuera de Serie 1 (2000) 317-333.

[30] Matney T.G., Sullivan A.D., Compatible stand and stock table for thinned and unthinned Loblolly pine stands, For. Sci. 28 (1982) 161-171.

[31] Mielikäinen K., The influence of low thinnings on the wood production and value of a pine stand, Folia For. 401 (1979) 1-23.

[32] Montero G., Río M., Ortega C., Ensayo de claras en una masa natural de pino silvestre en el Sistema Central, Invest. Agrar., Sist. Recur. For. 9 (2000) 147-177.

[33] Montero G., Cañellas I., Ortega C., Río M., Results from a thinning regime experiment in a Scots pine (Pinus sylvestris L.) natural regeneration stand in the Sistema Ibérico mountain range (Spain), For. Ecol. Manage. 145 (2001) 151-161.

[34] Pretzsch H., Stand density and growth of Norway spruce (Picea abies (L.) Karst.) and European beech (Fagus sylvatica L.): evidence from long-term experimental plots, Eur. J. For. Res. 124 (2005) 193-205.
[35] Pukkala T., Miina J., Kellomäki S., Response to different thinning intensities in young Pinus sylvestris, Scand. J. For. Res. 13 (1998) 141-150.

[36] Riitters K., Brodie J.D., Kao C., Volume versus value maximization illustrated for Douglas-fir with thinning, J. For. 80 (1982) 86-89.

[37] Río M., Régimen de claras y modelo de producción para Pinus sylvestris L. en los Sistemas Central e Ibérico, Tesis doctorales del INIA, serie: forestal 2, 1999.

[38] Río M., Montero G., Modelo de simulación de claras en masas de Pinus sylvestris L., Monografía INIA. Serie Forestal 3, 2001.

[39] Río M., Montero G., Bravo F., Analysis of diameter-density relationships and self-thinning in non-thinning even-aged Scots pine stands, For. Ecol. Manage. 142 (2001) 79-87.

[40] Río M., Montero G., Ortega C., Respuesta de los distintos regímenes de claras a los daños causados por la nieve en masas de Pinus sylvestris L. en el Sistema Central, Investig. Agrar., Sist. Recur. For. 6 (1997) 103-117.

[41] Rojo A., Montero G., El pino silvestre en la Sierra de Guadarrama, Ministerio de Agricultura, Pesca y Alimentación, Madrid, 1996.

[42] Searle S.R., Casella G., McCulloch C.E., Variance Components, Wiley Series in Probability and Mathematical Statistics, John Wiley \& Sons, 1992.

[43] Sharma M., Smith M., Burkhart H.E., Amateis R., Modeling the impact of thinning on height development of dominant and codominant loblolly pine trees, Ann. For. Sci. 63 (2006) 349-354.

[44] Valinger E., Elfving B, Mörling T., Twelve-year growth response of Scots pine to thinning and nitrogen fertilisation, For. Ecol. Manage. 134 (2000) 45-53.

[45] Varmola M., Salminen H., Timonen M., Thinning response and growth trends of seeded Scots pine stands at the artic timberline, Silva Fenn. 38 (2004) 71-83.

[46] Verbeke G., Molenberghs G., Linear mixed models for longitudinal data, Springer Series in Statistic, Springer Verlag, New York, 2000.

[47] Vonesh E.F., Chinchilli V.M., Linear and nonlinear models for the analysis of repeated measurements, Marcel Dekker, New York, 1997.

[48] Vuokila Y., The effect of thinnings on the yield of pine and birch stands, Comm. Inst. For. Fenn. 55 (1962).

[49] Zeide B., Thinning and growth: a full turnaround, J. For. 99 (2001) $20-25$. 